\title{
Absence of Rabies and Rabies-Related Lyssaviruses in Some Wild Animal Species in Enugu State, Nigeria
}

Lynda O Obodoechi ${ }^{1 *}$, Chidi O Anyaoha ${ }^{1}$, Nnenna E Ibezim ${ }^{1}$, Majesty E Alukagberie ${ }^{1}$, Chika I Nwosuh ${ }^{3}$, John A Nwanta ${ }^{1}$ and Chukwunyere O Nwosu ${ }^{2}$

${ }^{1}$ Veterinary Public Health and Preventive Medicine, University of Nigeria, Nsukka, Nigeria

${ }^{2}$ Veterinary Parasitology and Entomology, University of Nigeria, Nsukka, Nigeria

${ }^{3}$ National Veterinary Research Institute, Vom, Plateau State, Nigeria

\begin{abstract}
This study investigated the presence of rabies and rabies-related lyssaviruses in the brain, liver and spleen of some wild animal species (rodents, shrews and civet cats) slaughtered for human consumption in Enugu State, Southeastern Nigeria. Attempts were made to establish possible exposure potential of humans to rabies and rabies-related lyssaviruses through handling, processing, selling, buying and consumption of these wild animals and establish the species of the viral isolates if any. A total of four hundred and eighty four 329) wild animals were sampled for rabies and rabies-related lyssaviruses using florescent antibody technique (FAT), cell culture test for the isolation and Reverse Transcriptase Polymerase Chain Reaction (RT-PCR) for detection of lyssavirus nucleic acid. The animals sampled include eighty nine land squirrels (Xerus erythropus), seventy African giant rats (Cricetomysgambians), one hundred and one black rats eighty bush rats (Rattus fuscipes), seventy two shrews and seventy civet cats (Civetticitis civetta). The animals were collected fresh from hunters or markets, restaurants and bars where they are slaughtered and consumed as delicacy in the study area. There was no lyssavirus isolated from the three hundred and forty rodent samples (brain, liver, spleen) examined. Similarly, there was no lyssavirus isolated from the seventy civet cat samples (liver, spleen, brain). And samples (liver, spleen, brain) from seventy two shrews. The results of this study suggest that rodents and civet cats slaughtered for human consumption in Enugu State, Nigeria are free of rabies and rabies-related lyssaviruses. Therefore, there is no exposure potential to rabies or rabies-related lyssaviruses in those involved in the hunting, handling, processing, selling, buying and consumption of bush meat of these animal species. Also, the shrews and some other rodents such as black rats (Rattus rattus) were noted to be free of rabies and rabies-related lyssaviruses in the study area.
\end{abstract}

Keywords: Rabies; Rabies-related; Lyssaviruses; Rodents; Shrews; Civetcats

\section{Introduction}

The ecological persistence of pathogenic viruses has been the focus of many studies [1-3]. Nigeria occupies a strategic position wherever the history of lyssavirus is recounted [4]. This is because three species have been reported in the country. Lyssaviruses are negative stranded RNA viruses belonging to the family Rhabdoviridae [5]. Lyssaviruses are persistent and emerging infectious agents that cause disease in a range of domesticated and wild animal species including man [6]. The wild species reported to have been infected include foxes, ferrets, raccoons, bats, and several species of rodents [7]. Among the domesticated species, dogs and cats are mainly affected by the lyssaviruses but dogs have been established as the predominant vector of rabies in Nigeria [810]. Lyssavirus genus includes 11 recognized species [11]. The species type, Rabies virus (RABV) is distributed worldwide among carnivores and bats. Lagos bat virus (LBV) circulates among pteropid bats in subSaharan Africa with infrequent spill over into other mammals [12]. Mokola virus (MOKV) has been isolated in sub-Saharan Africa from shrews, domestic cats, dogs, rodents and humans [13,14]. Whereas rabies is probably the most important and definitive viral zoonosis world wide, Mokola virus infection has to date been reported from the African continent only [13]. Mokola virus was originally isolated in 1968 from pooled viscera of 3 insectivorous shrews (Crocidura spp.) from Mokola district of Ibadan, Nigeria [15]. It has been isolated twice from human beings from Nigeria in 1972 and since then there is no evidence of further isolation [16]. Rabies is one of the most important and widespread zoonotic diseases and it is with the exception of a few countries, a truly global dilemma [17-19]. Although dog is the predominant vector of rabies in Nigeria [9], rabies has been reported in wildlife species (lynx, civet cats, monkeys, insectivorous bats, chimpanzee, lion, hyrax) [2023]. In the USA, Canada, and Western Europe, where canine rabies has been controlled, dogs are responsible for very few cases of the disease. Rather, human rabies develops from bites of wild animals (especially bats, squirrels, rats, raccoons, skunks, and foxes) or occur in travelers bitten by dogs elsewhere in the world [24]. Mokola virus has been detected in Shrews and wild rodents but not bats, and its reservoir host is still uncertain [14]. In Nigeria, rabies cases still abound in spite of the yearly massive anti rabies vaccination, there may be thus an alternative reservoir for the virus. The overwhelming mortality associated with rabies infection makes it one of the most feared diseases of humans and animals. Dogs are the major animal reservoirs in the developing regions, wild life maintains cycle of infection even in developed countries and new viral aetiologic agents continue to emerge [25]. The domestic dog, Canis familaris, is recognized as the reservoir for classical rabies virus and the straw-coloured fruit bat for Lagos bat virus. The reservoir for

*Corresponding author: Lynda O Obodoechi, Veterinary Public Health and Preventive Medicine, University of Nigeria, Nsukka, Nigeria, Tel: +2348061591391; E-mail: onyinye.obodoechi@unn.edu.ng

Received May 31, 2017; Accepted July 24, 2017; Published July 25, 2017

Citation: Obodoechi LO, Anyaoha CO, Ibezim NE, Alukagberie ME, Nwosuh Cl et al. (2017) Absence of Rabies and Rabies-Related Lyssaviruses in Some Wild Animal Species in Enugu State, Nigeria. J Vet Sci Technol 8: 459. doi: $\pi 67491 \pi 0,001450$

Copyright: (c) 2017 Obodoechi LO, et al. This is an open-access article distributed under the terms of the Creative Commons Attribution License, which permits unrestricted use, distribution, and reproduction in any medium, provided the original author and source are credited. 
Mokola virus remains unidentified but shrews could be the reservoir [4]. The human cases of Mokola virus infection have demonstrated its zoonotic potential $[16,26]$ but a natural reservoir is yet to be identified [27]. The fact that all cases of Mokola virus infection in South Africa, as well as all but one from domestic animals from other countries in Africa [28-31] have been confined to cats, strongly suggests that the reservoir is to be found among their prey (shrews and rodents) as the virus has been isolated from them [15,32-34]. Mokola virus was last isolated in Nigeria in 1972 and since then, no further isolation has been done. Monitoring of animals especially the bush-meat in Africa has revealed that zoonotic viruses frequently spill over into the human populations that hunt, or manage the animals; which have provided significant insights into origins, geographic distributions, temperate limitations, and emergence potential of several important human pathogens [35]. In Enugu state, there is increase in wild life meat consumption with an increase in the population of people who hunt. Consequently, the rate of contacts between the indigenes and wild life is increased which could pose a very big risk should these animals be reservoirs of the viruses. It is against this background that this study was carried out to find out if lyssaviruses would be isolated from these animal species for a better understanding of the epidemiologic situation, circulation pattern and public health significance in order to establish control strategy in Enugu State in particular and Nigeria in general.

\section{Study Design}

The study was a one year cross- sectional study. This was achieved through collection of shrews civet cats and rodents from markets, bushes, restaurants and bars for viral isolation and identification from brain tissues and visceral organs (spleen and liver) using FAT, tissue cell culture in mouse neuroblastoma cell line (MNA) and RT-PCR.

\section{Sample collection}

Purposive sampling method was adopted for sample collection from markets where fresh rodents and wild cats exist and bars and restaurants where their meat are sold as delicacy for human consumption. However, some of the rodents and shrews were collected directly from hunters from purposively selected bushes where the wild animals reside.

A total of four hundred and eighty four animals were collected for lyssaviruses screening. The animals included were 89 land squirrels (Xerus erythropus), 70 African giant rats(Cricetomysgambians), 101 black rats Rattus rattus 80 bush rats (Rattus fuscipes), 72 shrews (Cocidura spp) and seventy Civet cats (Civetticitis civetta) were used for the study. The samples were stored at $-20^{\circ} \mathrm{C}$ until analysis.

Detection of rabies and rabies- related lyssaviruses was done using FAT and RT-PCR while isolation was done on mouse neuroblastoma cell line (MNA) as described by Zanoni et al. [36].

\section{Direct Fluorescent Antibody Technique (DFA)}

Glass slides were properly degreased and labeled accordingly. A known positive sample normally challenge virus strain (positive control) and a normal 3-week-old mice brain (negative control) were used as controls. Thin impression smears of the negative control, positive control and test brain samples were made on the centre of the properly labeled glass slides.

The smears were air-dried at room temperature and fixed in cold acetone contained in coplin jar for thirty minutes at $-20^{\circ} \mathrm{C}$. The slides were air-dried for thirty minutes at room temperature and the smears encircled with wax pencil. $150 \mu \mathrm{l}$ of the diluted aliquot of the FITC anti- rabies monoclonal globulin conjugate made by Fujirebio Diagnostics Inc. Malvern, PA, USA that detects the four African lyssaviruses (Rabies virus, Lagos bat virus, Mokola virus and Duvenhage virus) was added to cover the smears within the encircled areas of the slides in the moist chamber and incubated at $37^{\circ} \mathrm{C}$ for 30 minutes. Afterwards, the slides were properly washed in phosphate buffered saline $(\mathrm{pH} 8.5)$ for 30 minutes to remove the unbound DFA reagent in the smears. The slides were allowed to air-dry at room temperature. Two drops of $50 \%$ buffered glycerol mounting medium was added and cover slips were mounted and the slides were viewed under florescent microscope. The test impression and the positive and negative control impressions stained with FDI FITC anti- rabies monoclonal globulin were examined with a fluorescence microscope. A test impression was scored as positive when brilliant apple-green fluorescence was observed. The test is valid when brilliant apple-green fluorescence was observed in the positive control, but no apple- green fluorescence was seen in the negative control. A test impression was negative when no apple-green fluorescence was observed.

\section{Tissue cell culture in mouse neuroblastoma cell line (MNA)}

This procedure involved the isolation and culture of all lyssavirus from a homogenate of a suspect test specimen in mouse neuroblastoma cells (MNA) (ATCC HB-12317) from America Type Culture Collection Center, USA. Ten percent homogenate of the brain and pooled visceral organs (spleen and liver) were separately made using Phosphate buffered saline of pH 7.2 and antibiotic (a combination of Penicillin, streptomycin and Fungizone). This was clarified by centrifugation for 10 minutes at 10,000 $\mathrm{g}$ in a cold centrifuge and filtered using $0.45 \mu$ Millipore filter. Using 96 well cell culture plates $100 \mu$ of each sample was inoculated in quadruplet into $80 \%$ confluent MNA cells in DMEM (Dulbecco's Modified Eagle's Medium) without sodium pyruvate but with $10 \%$ fetal calf serum and $1.5 \mathrm{gm} /$ liter of sodium carbonate and incubated for four days at $37^{\circ} \mathrm{C}$ with $5 \% \mathrm{CO}_{2}$. The medium was harvested separately, labeled and stored at $-20^{\circ} \mathrm{C}$ while the plates were fixed in $80 \%$ cold acetone for 30 mins, washed and stained with fluorescent labeled antirabies conjugate. Positive samples showed bright 'apple' green fluorescence inclusions generally in the perinuclear area cells. A negative sample had no fluorescence and appeared dull green or red/green.

\section{Reverse Transcriptase Polymerase Chain Reaction (RT-PCR)}

RNA extraction: Total Viral RNA was extracted from pooled sample of the brain, spleen and liver using TRIzol ${ }^{\circ}$ reagent (invitrogen ${ }^{\mathrm{Tn}}$, U.S.A). The spleen and liver were included because previous isolates of Mokola virus were from pooled viscera organs.

Approximately $300 \mu \mathrm{l}$ of the sample was homogenized in 1000 $\mu \mathrm{l}$ of TRIzol Reagent and vortex mixed and incubated at room temperature (RT) for 5 minutes allowing for complete dissociation of the nucleoprotein complex. Two hundred microlitres of chloroform was added to the homogenate, vortex mixed and kept for 5 minutes at RT and then centrifuged at $14000 \mathrm{~g}$ for 10 minutes to separate the phases. Five hundred microlitres of the aqueous phase was transferred to a fresh sterile Eppendorf tube and $200 \mu \mathrm{l}$ of $75 \%$ ethanol was added and $500 \mu \mathrm{l}$ of isopropanol (SIGMA U.S.A) was added gently mixed and kept at RT for 10 minutes to enhance precipitation of the RNA. The RNA pellet was recovered by centrifugation at $14000 \mathrm{~g}$ for 10 minutes, washed with $1000 \mu \mathrm{l}$ of $75 \%$ ethanol and air-dried. The RNA pellet was then solubilized in $50 \mu \mathrm{l}$ of RNA suspension solution (DEPC treated water) (Thermo Scientific, USA) in heating block (Thermo Scientific, USA). The solubilized RNA was stored at $-20^{\circ} \mathrm{C}$. 
Citation: Obodoechi LO, Anyaoha CO, Ibezim NE, Alukagberie ME, Nwosuh Cl, et al. (2017) Absence of Rabies and Rabies-Related Lyssaviruses in Some Wild Animal Species in Enugu State, Nigeria. J Vet Sci Technol 8: 459. doi: 10.4172/2157-7579.1000459

Page 3 of 5

Reverse Transcription (RT): Approximately $2 \mu$ of the total RNA was heat-natured and annealed with messenger sense primers JW12 and Lys 001 at $65^{\circ} \mathrm{C}$ for 2 minutes and cooled on ice for 1 minute. This was immediately followed by reverse transcription performed at $37^{\circ} \mathrm{C}$ for 60 minutes in a $0.5 \mu$ reaction containing 200 units of Murine Moloney Leukemia Virus Reverse Transcriptase (M-MLV, USB ${ }^{\text {tw }}$ ), 20 units of RNasin ribonuclease inhibitor (promega), 4.0 of dNTP mixture, 2.0 of DTT and 2.0 reverse transcriptase reaction buffers. At the end of the reverse transcription reaction, the cDNA mixture was inactivated at $85^{\circ} \mathrm{C}$ for 5 minutes, $37^{\circ} \mathrm{C}$ for 20 minutes then stored at $-20^{\circ} \mathrm{C}$ (Plate 1$)$.

Polymerase Chain Reaction (PCR): In brief, a $50 \mu$ lreaction mixture containing $2 \mu \mathrm{l}$ of the cDNA, $0.5 \mu$ lof the Takara Taq DNA polymerase (Takara Biotechnology, Japan), $4 \mu \mathrm{l}$ of $10 \mathrm{mM}$ DNTP mixture, $4 \mu \mathrm{l}$ each of $10 \mathrm{pmol}$ Lys 001 and $550 \mathrm{~B}, 0.5 \mu \mathrm{l}$ of $10 \mathrm{X}$ Taq polymerase reaction buffer and made up to $50 \mu \mathrm{l}$ with nuclease free water. The amplification was carried out with an ABI 9700 thermocycler with an initial denaturation at $94^{\circ} \mathrm{C}$ for one minute, followed by 40 cycles of $\left(94^{\circ} \mathrm{C}\right.$ for 30 seconds, $37^{\circ} \mathrm{C}$ for 30 seconds and $72^{\circ} \mathrm{C}$ for 90 seconds) and a final extension at $72^{\circ} \mathrm{C}$ for 10 minutes. The amplified DNA products were visualized under UV transillumination after electrophoresis through $1 \%$ ethidium bromide stained agarose gels (Labnet, power station 300) with a 100 bp DNA ladder as the molecular weight maker (Promega).

\section{Results}

Out of the three hundred and forty brains of rodents, seventy two shrews and 70 brains of civet cats sampled and examined on florescent antibody test, none $(0 \%)$ was positive for rabies or rabies-related lyssaviruses nor isolated on mouse neuroblastoma cell line (MNA). In addition, out of the total 329 pooled brain, liver and spleen, there was no rabies or rabies-related lyssavirus nucleic acid detected on RTPCR test techniques. On the other hand, the positive control samples remained positive while the negative controls were also negative for all the test techniques used.

\section{Discussion}

In the present study, a total of three hundred and forty samples made up of brain, liver and spleen homogenates of rodents (89 squirrels, Xerus erythropus; 80 bush rats, Rattus fuscipes; and 70 African giant rats Cricetomys gambianus and 101 black rats, Rattus rattus were analyzed for the presence of rabies and rabies-related viruses. The brain, spleen and liver of these animal species were examined using FAT, RT-PCR and tissue cell culture in mouse neuroblastoma cell line (MNA) for viral isolation. Although, the FAT has been recommended by the OIE and $\mathrm{WHO}$, and used worldwide for the diagnoses of rabies [8], it failed to detect any lyssavirus antigen in the present study because none of the samples had lyssavirus antigen. However, in spite of the FAT being the most common, rapid and sensitive diagnostic test for rabies, other supplementary diagnostic methods are employed when a questionable FAT result is obtained in order to arrive at a definite conclusion.

Consequently, several molecular biology-based diagnostic methods which target the nucleic acids of the causative agents have been employed for such further confirmatory tests. Accordingly, diagnostic methods based on RT-PCR have been confirmed to be useful and sensitive in detecting viruses that cause lyssaviral diseases [24]. In the present study, no lyssavirus nucleic acid was detected using the RTPCR.

Virus isolation in cell culture is fast and results can be given in 24-48 hours. The cell lines most suitable for virus isolation are of neural origin and the most commonly used cell line is the murine neuroblastoma cell line Neuro-2a. Other cell lines which are used but may not be as sensitive as Neuro-2a include chicken embryo-related (CER) and baby hamster kidney (BHK 21) cells. In this research, we were not able to isolate any rabies nor rabies- related lyssaviruses using MNA cell line since there was no growth of any virus. The $0 \%$ prevalence of rabies and rabies-related lyssavirus in the animal species sampled suggests that there may not be lyssavirus in these animal species in the study area. Inspite of isolations of rabies virus in wildlife, the role of wildlife in the

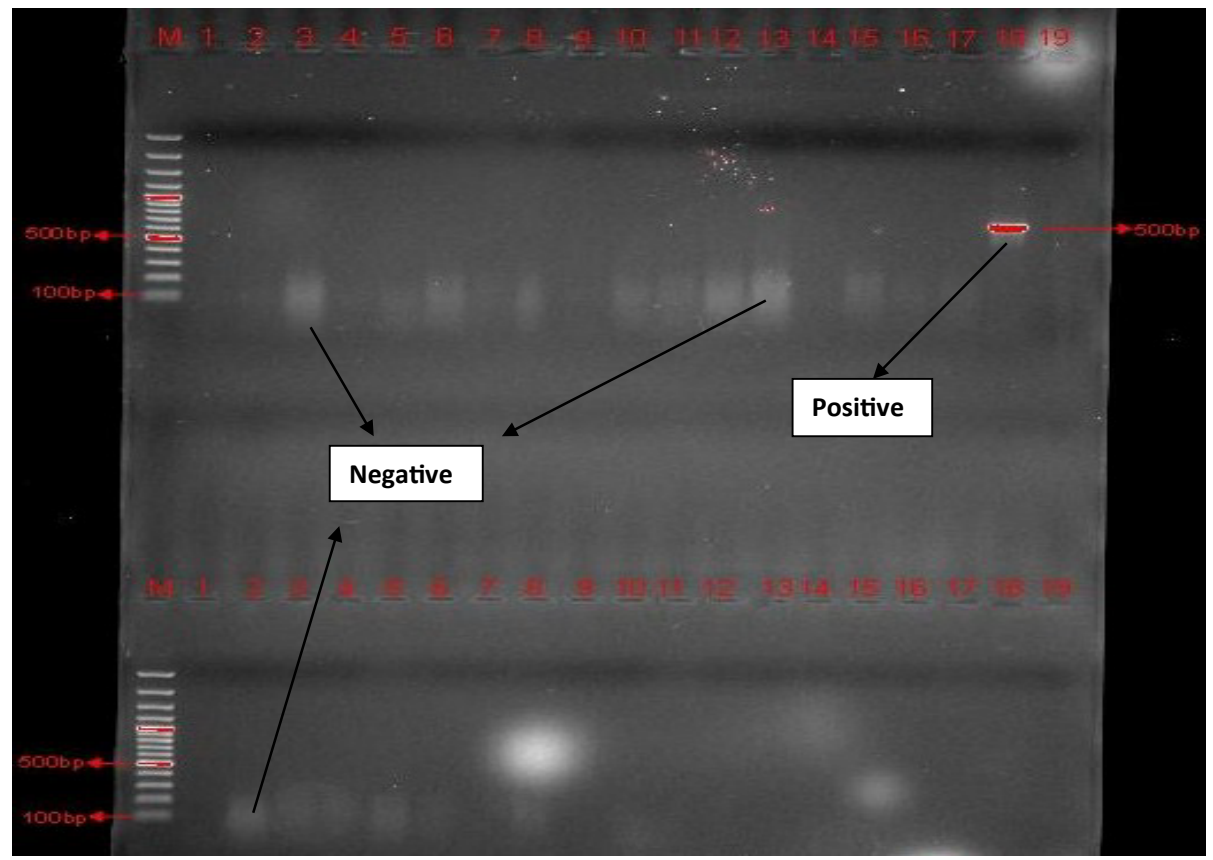

Plate 1: Annotated picture of the RT-PCR result showing all samples to be negative except for the positive control trapped at 500 bp. 
transmission of rabies in Nigeria is still not clearly defined. Bougler and Hardy failed to isolate rabies virus from the brains and salivary glands of 1,913 rats collected in Lagos [37]. The present findings agree with the recommendations of the CDC that bites from squirrels and rats do not call for post exposure prophylaxis as they rarely carry rabies [38]. According to CDC, squirrels and rats may get rabies, but their chances of contracting it are slim to none. In order for these animals to get rabies, they would have to hang around with animals that are common carriers. However, this does not usually happen because many of the animals that would carry rabies (dogs, cats, foxes) are arch enemies of rodents which, ordinarily, would avoid them. In addition, squirrels are so quick at evasion and with 180 degree vision; the chances of them being bitten by rabid animal are very remote [39].

According to CDC, rats almost never carry rabies and are not considered a serious rabies risk. Rabies transmission in rats is extremely rare, not because rats have dry bites but because they almost never carry rabies, presumably because rats do not survive the attack of a rabid animals like raccoons, skunks, foxes, cats or dogs. Most animals that carry rabies, if they get hold of rats and squirrel would more likely kill them and thus would end the possibility of such rats and squirrels carrying and transmitting the disease. This therefore reaffirms the public health community's general assumption that rodents, with the exception of large-bodied species, carry little risk of transmitting RABV [40]. The findings of this study is also in harmony with Winkler, who stated that although rodents may become infected with rabies, there is actually little or no naturally occurring rodent rabies [41]. This however, does not rule out rodents as factor in rabies epidemiology in Nigeria. First, there is belief that a bite from a rodent, the ground squirrel (Xerus erythropus) results in madness and death one to six months after the bite and with Mokola virus been isolated from shrews. Reports of Oboegbulem and Garba showed that in Nigeria, only 1 rat was positive for rabies between 1991 and 2005 [9,42]. Similarly, the findings of this study ( $0 \%$ prevalence) is lower than the prevalence of $0.04 \%$ recorded in rats in Poland (WHO), $1 \%$ in rats in Isreal and $4.7 \%$ in rats in Norway $[8,24,25]$. Rodents represented less than $1 \%$ of all species tested for rabies in the United States of America, and virtually all of those tested and found rabid were large species such as woodchucks (Marmota monax) and beavers (Castor canadensis) [39,43]. Winkler reviewed rabies in rats over 18 years period (1953 to 1970) and reported that only 39 rats were found rabid in the United States of America; only 11 rabid rats were rabid between 1953 and 1955 while during the three year period of 1968-1970, only 2 rats were rabid [41]. The result of this study does not agree with the work done by some authors in Nigeria and other countries, who have implicated rodents in the maintenance of RABV but critical data to support these contentions are elusive $[23,44,45]$.

The present study recorded $0 \%$ prevalence of rabies and rabiesrelated lyssaviruses in shrews. Mokola virus was first isolated from shrews (Cocidura spp) in 1968 [46]. Since the initial isolation was from the visceral organs, pooled samples of the brain, spleen and liver were equally analyzed using mouse neuroblastoma cell line (MNA) and there was no viral growth. This suggests that there may not be rabies or rabies-related lyssaviruses in the animals sampled in the study area. The $0 \%$ prevalence of Mokola virus recorded in shrews in this study agrees with Kantakamalakul who investigated five hundred rodents and shrews for rabies virus using direct immunoflorescnce and reported $0 \%$ prevalence [47]. Kgaladi et al. after his survey on Moklola virus (19682012) reported that although, the first isolates of Mokola virus were from Nigeria and other Congo basin countries, all reports over the past 20 years have been from Southern Africa [27].
The results obtained from this study showed $0 \%$ prevalence of rabies and rabies-related lysaviruses in civet cats since we were not able to isolate any virus suggesting that rabies and rabies-related lyssaviruses do not exist in the civet cats sampled in the study area. Civet cats are nocturnal in habit and rarely found during the day. Dogs which are the main reservoir of rabies in Nigeria often move around during the day, thus reducing the chances of interaction between civet cats and dogs [9]. However, this result is not in harmony with the works of Kasali who reported a case of rabies in a wild cat in Jos, Nigeria and Ogunkoya who reported a prevalence of $21.4 \%$ in 22 civet cats screened in Bauchi State, Nigeria $[20,23]$. Furthermore, Umoh and Belino incriminated civet cats as wild life reservoirs of rabies in Nigeria [48].

The $0 \%$ prevalence of rabies and rabies related lyssavirus observed in the wild animal species studied, agrees with the previous works done by researchers like Okoh who reported $0 \%$ prevalence of rabies in over 200 wild animals tested between the period 1923 and 1970 [44]. Furthermore, the National Veterinary Research Institute (NVRI) Vom, Nigeria diagnosed 538 cases of rabies between 1970 and 1978 with 504 (94\%) of the cases in dogs and the rest in domestic cats. This therefore conforms to previous reports that wild life rabies is not given prominence in some countries like Nigeria were dogs are the major reservoirs of rabies $[7,9,49]$.

\section{Conclusion}

In conclusion, the $0 \%$ prevalence of rabies and rabies-related lyssaviruses observed in the rodents shrews and civet cats examined in Enugu State, Nigeria suggests that lyssaviruses may not exist in these animal species in the study area at the time of the study. It further suggests that these animal species may not be important in the epidemiology of lyssaviruses in the study area.

\section{References}

1. Bartlett MS (1960) The critical community size for measles in the United States J Royal Statistical Soc 123: 37-44.

2. Black FL (1966) Measles endemicity in insular populations: Critical Community six and its evolutionary implications. J Theor Biol 11: 207-211.

3. Anderson RM, May RM (1991) Infectious disease of humans. New York Oxford University Press.

4. Dzikwi AA, Garkida AD, Umoh JU (2011) World Rabies Day: Efforts Towards Rabies Awareness in Zaria, Nigeria. Nigerian Vet J 32: 133-136.

5. Tordo N, Kouknetzoff A (1993) The rabies virus genome: An overview. Onderstepoort J Vet Res 60: 263-269.

6. Okoh AEJ (2007) Rabies in Nigeria: Issues and Challenges. 6th Inaugura lecture, University of Agriculture Makurdi, 26th September, 2007. pp. 1-2.

7. Bishop GC, Durrhicim, Kloeck PE, Godlonton JP, Bingham J, et al. (2003) Rabies: Guide for the Medical, Veterinary and allied Professions. I edition. Government Printer Pretoria.

8. World Health Organization (1992) WHO Expert Committee on Rabies Technical Report Series No. 824, Geneva.

9. Oboegbulem SI (1994) Rabies in man and animals. 1st edition. Fidelity Publishers Enugu pp. 5-15, 238.

10. Cleaveland S, Kaare M, Knobel D, Laurenson MK (2006) Canine vaccinationproviding broader benefits for disease control. Vet Microbiol 117: 43-50.

11. Kuzmin IV, Mayer AE, Niezgoda M, Markotter W, Agwanda B, et al. (2010) Shimoni bat virus, a new representative of the Lyssavirus genus. Virus Res 149: $197-210$

12. Markotter W, Kuzmin I, Rupprecht CE, Nel LH (2008a) Phylogeny of Lagos bat virus: challenges for lyssavirus taxonomy. Virus Res 135: 10-21.

13. Nel L, Jacobs J, Jafta J, Von Teichman B, Bingham J (2000) New cases of Mokola virus infection in South Africa: a genotypic comparison of Southern 
Citation: Obodoechi LO, Anyaoha CO, Ibezim NE, Alukagberie ME, Nwosuh Cl, et al. (2017) Absence of Rabies and Rabies-Related Lyssaviruses in Some Wild Animal Species in Enugu State, Nigeria. J Vet Sci Technol 8: 459. doi: 10.4172/2157-7579.1000459

African virus isolates. Virus Genes 20: 103-106.

14. Sabeta CT, Markotter W, Mohale DK, Shumba W, Wandeler Al, et al. (2007) Mokola virus in domestic mammals, South Africa. Emerg Infect Dis 13: 1371 1373

15. Shope RE, Murphy FA, Harrison AK, Causey OR, Kemp GE, et al. (1970) Two African viruses serologically and morphologically related to rabies virus. $J$ Virol 6: 690-692.

16. Familusi JB, Moore DL (1972) Isolation of a rabies related virus from the cerebrospinal fluid of a child with aseptic meningitis. African J Med Sci 3: 93-96.

17. Blancou J (1988) Epizootiology of rabies: Eurasia and Africa. In: Rabies. Campell JB \& Chalton KM (eds.) Kluwer Academic publishers, Boston, 243-265.

18. World Health Organisation (1989) WHO expert committee on Rabies: WHO Technical Report, WHO. Geneva.

19. World Health Organisation (1991) WHO expert Committee on Rabies: WHO Technical Report, WHO. Geneva

20. Kasali OB (1977) Rabies in a civet cat (virtacirtta); case report. Vet Rec 100: 291.

21. Okoh AEJ (1986a) Dog ecology with reference to surveillance of rabies and characterization of rabies virus isolates in Plateau State, Nigeria. Ahmadu Bello University, Zaria.

22. Enurah LU, Ocholi RA, Adenryi KO, Ekwonu MC (1988) Rabies in civet cat in Jos Zoo, Nigeria. Br Vet J 144: 515-516.

23. Ogunkoya $A B$ (2008) Review of rabies and problems of rabies in Nigeria Proceedings of the National Conference/Workshop on Rabies, IDR-ABU, Zaria, Nigeria.

24. Smith JS (1996) New aspects of rabies with emphasis on epidemiology, diagnosis, and prevention of the disease in the United States. Clin Microbio Rev 9: 166-176.

25. Rupprecht CE, Willoughby R, Slate D (2006) Current and future trends in the prevention, treatment and control of Rabies. Expert Rev Anti Infect Ther 4: 1021-1036.

26. Warrell MJ, Warrell DA (2004) Rabies and other lyssavirus diseases. Lancet 363: 959-969.

27. Kgaladi J, Wright N, Coertse J, Markotter W, Martson D (2013) Diversity and Epidemiology of Mokolavirus. PLoS Negl Trop Dis 7: e2511.

28. Foggin CM (1982) Atypical rabies virus in cats and a dog in Zimbabwe. Vet Rec 110: 338.

29. Foggin CM (1983) Mokola virus infection in cats and a dog in Zimbabwe. Vet $\operatorname{Rec} 113: 115$

30. Foggin CM (1988) Rabies and rabies-related viruses in Zimbabwe: Historical, virological and ecological aspects. PhD Theses, University of Zimbabwe, Harare.
31. Mebatsion T, Cox JH, Frost JW (1992) Isolation and characterization of 115 street rabies virus isolates from Ethiopia by using monoclonal antibodies: Identification of 2 isolates as Mokola and Lagos bat viruses. J Infect Dis 166 972-977.

32. Kemp GE, Causey OR, Moore DRL, Odelola A, Fabiyi A (1972) Serological evidence of infection of dogs and man in Nigeria by lyssaviruses (family Rhabdoviridae). Trans R Soc Trop Med Hyg 21: 356-359.

33. Le Gonidec G, Rickenbach A, Robin T, Heme G (1978) Isolation of a strain of Mokola virus in Cameroon. Ann Microbiol 129A: 245-249.

34. Saluzzo JF, Rollin PE, Daugard C, Digoutte JP, Georges AJ, et al. (1984) First isolation of the Mokola virus from a rodent (Lophuromys sikapusi). Annalies de I'Institut Pasteur: Virology 135E: 57-66.

35. Wolfe ND, Heneioe W, Carr JK, Garcia AD, Shanmugam V, et al. (2007) Naturally acquired simian retrovirus infections in central African hunters. Lance 363: 932-937.

36. Zanoni RG, Hornlimann B, Wandler AI (1990) Rabies tissue culture infection test as an alternative for mouse inoculation test. Altex 7: 15-23.

37. Bougler LR, Hardy J (1960) Rabies in Nigeria. West Africa Med J 9: 233-234

38. Centers for Disease Control and Prevention (1969) Wild rats and Disease.

39. Centers for Disease Control and Prevention (2011) Rabies and pet risk.

40. Real LA, Childs JE (2005) Spatial-temporal dynamics of rabies in ecologica communities. Collinge 12: 170-186.

41. Winkler WG (1973) Rabies in the United States, 1951-1970. J Infect Dis 125 674-675.

42. Garba A (2011) What you must know about Rabies. 1st edn. Sanies Press Jos Nigeria.

43. World Health Organisation (1998) WHO World survey of Rabies. Report Series No. 34, Geneva.

44. Okoh AEJ (1986b) Investigation of possible rabies reservoirs in rodents in Nigeria. Int J Zoonoses 13: 1-5

45. Summa ME, Carrieri ML, Favoretto SR, Chamelet El (1987) Rabies in the state of Sao Paulo: the rodents question. Rev Inst Med Trop S Paulo 29: 53-58.

46. Kantakamalakul W, Siritantikorn S, Thongcharoen $P$ Singchai $C$, Puthavalthana $P(2003)$ Prevalence of rabies virus and Hantaan virus infections in commensal rodents and shrews trapped in Bankok. J Med Assoc Thai 86: 1008-1014.

47. Shope RE (1978) Rabies in viral infections of Humans: Epidemiology and control. pp: 351-363.

48. Umoh JU, Belino ED (1979) Rabies in Nigeria. A historical review: Int J Zoonoses 6: 41-48.

49. Fooks AR, Brookes SM, Johnson N, McElhinney LM, Hutson AM (2003a) Epidemiol Infect 131: 1029-1039. 